\section{1. 緒言}

塩案ガスの水に対する溶解度については，従来より多 くの研究がなされているが1 旅厚食塩水の塩素ガス 溶解度の文献は小なく ${ }^{7,8}$, 食塩濃度, 塩素分圧, 温度, $\mathrm{pH}$ K対する影響についての実測值はほとんと報告され ていない。

筆者はここに，水銀法食塩電解液の脱塩素に関する基 礎的設計資料として，必要な塩素ガス溶解度について研 究し, 食塩濃度 $200 \sim 300 \mathrm{~g} / \mathrm{L}$, 塩素分圧 $0.1 \sim 1.0$ 気王, 温度 $30 \sim 70^{\circ} \mathrm{C}$ に扰方塩素ガス溶解度を実測し，その 值をノモグラフで示した。

\section{2. 既往の研究}

水に溶解した塩系は，分子状態の遊離塩素と次亜塩素 酸の状態として存在し，これらの総計がいかゆる溶解度 として測定值にあらわれる。塩素ガスの水に溶解する場 合の加水分解反応付しては，(1) 式が成立する。

$$
\mathrm{Cl}_{2}(\mathrm{aq})+2 \mathrm{H}_{2} \mathrm{O}=\mathrm{H}_{3} \mathrm{O}^{+}+\mathrm{Cl}^{-}+\mathrm{HClO}
$$

Adams and Edmonds ${ }^{2}$ は全塩素を気相塩素分圧に対 して測定して，(2) 式の関係式を導いた。

$$
C=\frac{70.9 \cdot r \cdot P}{\mu R T}+\sqrt[3]{\frac{70.9 K_{1} \gamma P}{\mu R T}}
$$

$C$ と $P$ の関係は（2）式で示されるように，塩素分圧 の低い所では直楾関係から偏位を示すが，この偏位は加 水分解炕よる $\mathrm{HClO}$ の存在によるるのである。加水分 解の平衡関しては, Jakowkin ${ }^{22}$, 荻沢氏3,4), Foerst$e r^{5)}$, Whitney \& Vivian ${ }^{62}$ の文献がある。G. N. Lewis ${ }^{6)}$ は Jakowkin の測定値から温度 $0 \sim 100^{\circ} \mathrm{C}$ の加水分解佰 数を算出している。

また荻沢氏は遊離塩紊と塩素分圧の関係を測定し，塩

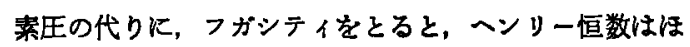
ぼ一定値になることを示した。

以上説明した水一塩素系に対する既往の結果は, 濃厚な 食塩水の塩素の溶解の場合にも成りたつわけであるが， Izard》は溶解塩素がさらK $\mathrm{Cl}_{3}$-イオンの状態で存在す ることを提唱した。すなわち濃厚食塩水の活性塩素瀑度 $\left[\mathrm{Cl}_{2}\right.$ (active)]は(3) 式に示す $\mathrm{Cl}_{2}(\mathrm{aq}), \mathrm{Cl}_{3}-\mathrm{HClO}$

\footnotetext{
- 昭和 33 年 3 月 25 日受理
}

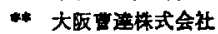

の濃度の総和としてあらわされる。

$$
\left[\mathrm{Cl}_{2}(\text { active })\right]=\left[\mathrm{Cl}_{2}(\mathrm{aq})\right]+\left[\mathrm{Cl}_{3}-\right]+[\mathrm{HClO}]
$$

Lars Barr ${ }^{8}$ ) は塩素の溶解度を温度 $60^{\circ} \mathrm{C}$, 食塩灌度 $310 \mathrm{~g} / \mathrm{L}$ の食塩水の場合についてて計算 $\mathrm{L}$, 各成分の港度 に対して (4) 式の関係を求めている。

$$
\begin{aligned}
& p\left[\mathrm{Cl}^{-}\right] \doteqdot 0.6, \quad p\left[\mathrm{Cl}_{2}(\mathrm{aq})\right] \doteqdot 2.5, \\
& \quad p\left[\mathrm{Cl}_{3}^{-}\right] \doteqdot 2.1, \quad p[\mathrm{HClO}] \doteqdot-\mathrm{pH}+6.2
\end{aligned}
$$

（4）式の関係は，つきに示す仮定のるとに求められたも のである。すなわちイオンの活量俰数は 2 12 の $\mathrm{pH}$ 範 囲で一定で 0.9 に等しいとし， $\left\{\mathrm{Cl}_{3}{ }^{-}\right\} /\left\{\mathrm{Cl}_{2}(\mathrm{aq})\right\}$ の関 係恃 $25^{\circ} \mathrm{C}$ と $60^{\circ} \mathrm{C}$ で一定であると仮定して Izard の求 めた $25^{\circ} \mathrm{C}$ の実測值をとのまま $60^{\circ} \mathrm{C}$ の条件に使い, 計 算によってその溶解度を求めている。 $\mathrm{Cl}_{3}$-の濃度は直接 には測定困難な数值であるから, 本研究の目的には $\mathrm{Cl}_{3}{ }^{-}$ の濃度を問題にするより次節において説明する方法によ って $\mathrm{Cl}_{2}(\mathrm{aq}) と \mathrm{Cl}_{3}$-の濃度の和を実測し，種々の条件， 塩素分厈, 温度, 食塩濃度, $\mathrm{pH}$ に対する塩索の溶解度 の影響を研究する方が実際的であるように思われる。

\section{3. 実験装是および方法}

食塩水は純粋な食塩を溶解して調整し, Fig. 1 k示 した $300 \mathrm{cc}$ 容量の硝子製吸収㩧 a K入れ，恒温槽 bで温 度を一定に保った。

塩素ガスは塩素ボンベより送られ，オリフィスメータ iを通し，調節コック h Kより流量を調節した後，硝子 ファイバーを充填したガスストレーナc c通し，佰温槽 に入れてある加熱コイル d, トラッブ $\mathrm{e}$ を通して吸収埥 a に吹込む。吸収嚗はガスの分散をよくするため，分散 管 $\mathrm{j} か ゙$ 設けられている。また，gの管はマノメーターに 接続して吸収嚗中の任力を測定する。ガスの排出はfの 管により，kのトラップを通して行われる。また，ガス 分析の試料は1からガスビニレットで採取し, 食塩水の 温度の測定を $\mathrm{n}$ の温度計により行った。塩素ガスが䬶和 されると， $\mathrm{m}$ の取出口がらピベットを入れ，一定容積の 食塩水試料を採取した。

塩菜の溶解度は，沃度カリーチ方硫酸ソーダの方法に よる分析から求めた。塩素分王と溶解度を求める実験化

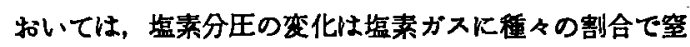



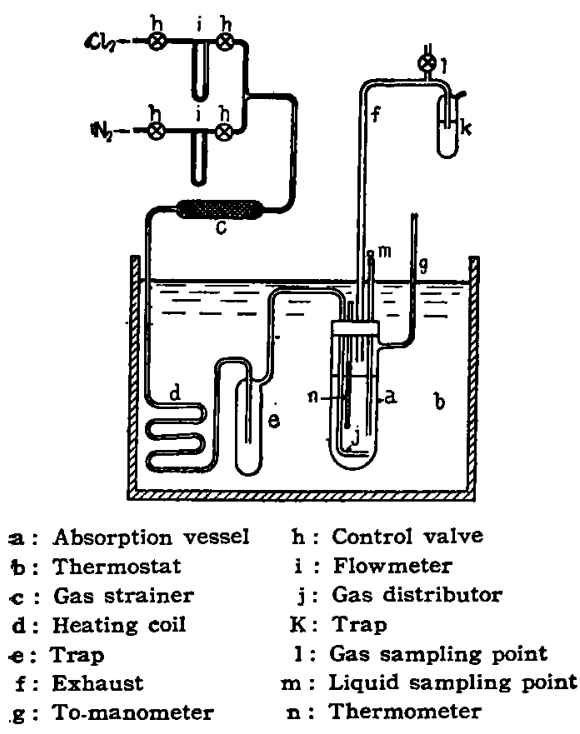

Fig. 1 Diagram of experimental apparatus

索ガスを混をることによって行われた。塩素ガスと窒素 ガスはオリフイスメータ：の示す流量によって，調節コ ックを適当に開閉することによりその割合を調節し，四 収後の排出ガスの分析から $\mathrm{Cl}_{2}$ と $\mathrm{N}_{2}$ の比率を測定し, 四収垬中の圧力から水蒸気仕を補正して塩素分圧を求め た。また，溶液の $\mathrm{pH}$ は硝子電極によって測定した。

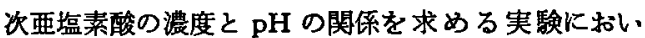
ては，あらかしめ食塩水に適当量の固形苛性ソーダを加 え, 溶解しててルカy性とし, 上述の方法に上って塩素 ガスを吸収飽和させて食塩水の溶解塩素 (活性塩素量) を測定し， pH I の食塩水について，同し条件で飽和さ れた溶解塩素量を差引いて求めた。

\section{4. 実稌䊅果と考察}

濃厚食塩水の塩素溶解度, すなわち $\left[\mathrm{Cl}_{2}(\mathrm{aq})\right]$ は (3) 式に示したよ $3 k\left[\mathrm{Cl}_{2}(\mathrm{aq})\right],\left[\mathrm{Cl}_{3}{ }^{-}\right],[\mathrm{HClO}]$ の総和 としてあらわされる。これらの値と食塩水の $\mathrm{pH}$ との関

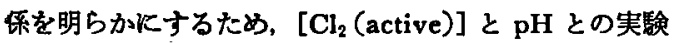
結果の二例を Fig. 2 飞示した。同図は $p\left[\mathrm{Cl}_{2}\right.$ (active)] vs. $\mathrm{pH}$ を点聂したすのであゆ， $\mathrm{pH} 1 \sim 2$ までは $\left[\mathrm{Cl}_{2}\right.$ (active)]は変化なく， pH 3 から次第に增加している。 最初の段階では [HClO] $\fallingdotseq 0$ であって, [Cl 2 (active)] $\doteqdot\left[\mathrm{Cl}_{2}\right.$ (aq) $]+\left[\mathrm{Cl}_{3}{ }^{-}\right]$そ考えられ, しかる一定值を示し でり，pH3からの上年は [HClO] が增加したために 上るすのと解せられる。[Cl $(\mathrm{aq})]+\left[\mathrm{Cl}_{3}\right.$ - $]$ は水菜イオ ン浱度变化の大きい $\mathrm{pH} 1$ から 2 の篹囲で実験結果が示 てているよろに一定であって，さらに高い $\mathrm{pH}$ 籁囲にお

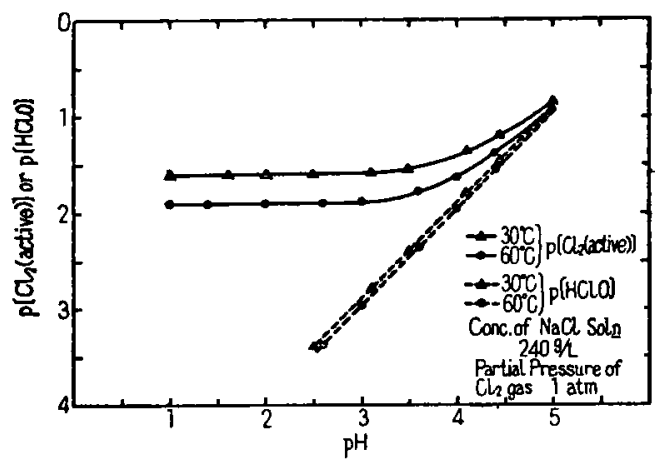

Fig. 2 Correlation between $\mathrm{pH}$ and $\mathrm{p}[\mathrm{HClO}]$ and $\mathrm{p}\left[\mathrm{Cl}_{2}\right.$ (active) $]$ in Conc. $\mathrm{NaCl}$ soln

Table 1 Experimental value $a$ of Eq. (5) at $P=1$

\begin{tabular}{cccc} 
& \multicolumn{3}{c}{ Concentration of $\mathrm{NaCl}$ soln $[\mathrm{g} / \mathrm{L}]$} \\
\hline$\left[{ }^{\circ} \mathrm{C}\right]$ & 200 & 240 & 300 \\
\hline 30 & 5.95 & 5.93 & 5.91 \\
40 & 5.97 & 5.94 & 5.92 \\
50 & 5.97 & 5.95 & 5.93 \\
60 & 5.98 & 5.96 & 5.95 \\
70 & 5.99 & 5.99 & 5.93
\end{tabular}

いて不変であるとすると，任意の $\mathrm{pH} の\left[\mathrm{Cl}_{2}\right.$ (active) $]$ そ $\mathrm{pH} 1 \sim 2$ の $\left[\mathrm{Cl}_{2}\right.$ (active)] の差がその $\mathrm{pH}$ での [HClO] をあらわすことになる。この方法に上って求め た $p$ [HClO] と $\mathrm{pH}$ の関係は Fig. 2 に示されるよう に, 直線関係であらわされ，その直線の傾斜から（5）式 が求められる。

$$
p[\mathrm{HClO}]=-\mathrm{pH}+a
$$

$a$ は塩素分圧，食塩水食塩濃度，温度によって定まる 亘数であり, 塩菜分压 1 気圧, 食塩水食塩濃度200 300 $\mathrm{g} / \mathrm{L}$, 温度 $30 \sim 70^{\circ} \mathrm{C}$ について央測より求めた数値を Table 1 に示した。

（5）式の関保は，また，食塩水中の $\mathrm{H}_{3} \mathrm{O}^{+}, \mathrm{Cl}_{2}(\mathrm{aq})$, $\mathrm{HClO}, \mathrm{Cl}^{-}$の間の平衡関保式 (6) 式から導くことがで きる。

$$
\frac{\left\{\mathrm{H}_{3} \mathrm{O}^{+}\right\}\left\{\mathrm{Cl}^{-}\right\}\{\mathrm{HClO}\}}{\left\{\mathrm{Cl}_{2}(\mathrm{aq})\right\}}=K_{2}
$$

ここに\{＼$は各成分の活量をあらわし，各活量およ }$ び $\mathrm{K}_{2}$ の逆数の対数をとると（7）式が求められる。

$$
\begin{aligned}
p\{\mathrm{HClO}\}= & -\mathrm{pH}+p\left\{\mathrm{Cl}_{2}(\mathrm{aq})\right\} \\
& -p\left\{\mathrm{Cl}^{-}\right\}+p K_{2}
\end{aligned}
$$

塩素分压, 食塩水食塩濃度, 温度が一定の条件では, $p\left\{\mathrm{Cl}_{2}(\mathrm{aq})\right\}, p\left\{\mathrm{Cl}^{-}\right\}, p K_{2}$ は一定であるから，おのおの の和を定数 $a_{0}$ とすると，(7) 式は（8）式となる。 
Table 2 Experimental Results

\begin{tabular}{|c|c|c|c|c|c|c|c|c|}
\hline \multirow[b]{2}{*}{ temp. } & \multicolumn{8}{|c|}{ Concentration of $\mathrm{NaCl}$ solntion } \\
\hline & \multicolumn{2}{|c|}{$\begin{array}{c}217 \mathrm{~g} / \mathrm{L} \\
P[\mathrm{Cl}(\mathrm{aq})] \\
{[\mathrm{atm}][\mathrm{M} / \mathrm{L}]}\end{array}$} & \multicolumn{2}{|c|}{$\begin{array}{c}250 \mathrm{~g} / \mathrm{L} \\
P\left[\mathrm{Cl}_{2}(\mathrm{aq})\right] \\
{[\mathrm{atm}][\mathrm{M} / \mathrm{L}]}\end{array}$} & \multicolumn{2}{|c|}{$\begin{array}{c}280 \mathrm{~g} / \mathrm{L} \\
P\left[\mathrm{Cl}_{\mathrm{g}}\left(\mathrm{aq}_{\mathbf{a}}\right)\right] \\
{[\mathrm{atm}][\mathrm{M} / \mathrm{L}]}\end{array}$} & \multicolumn{2}{|c|}{$\begin{array}{c}300 \mathrm{~g} / \mathrm{L} \\
P[\mathrm{Cl}(\mathrm{aq})] \\
{[\mathrm{atm}][\mathrm{M} / \mathrm{L}]}\end{array}$} \\
\hline $\begin{array}{c}30 \\
" \\
" 1 \\
" 1\end{array}$ & $\begin{array}{l}0.10 \\
0.20 \\
0.30 \\
0.45 \\
0.55\end{array}$ & $\begin{array}{l}0.0030 \\
0.0055 \\
0.0080 \\
0.0123 \\
0.0145\end{array}$ & $\begin{array}{l}0.18 \\
0.35 \\
0.45 \\
0.55 \\
0.65\end{array}$ & $\begin{array}{l}0.0045 \\
0.0083 \\
0.0108 \\
0.0133 \\
0.0160\end{array}$ & $\begin{array}{l}0.15 \\
0.21 \\
0.33 \\
0.43 \\
0.53\end{array}$ & $\begin{array}{l}0.0035 \\
0.0048 \\
0.0073 \\
0.0095 \\
0.0115\end{array}$ & $\begin{array}{l}0.14 \\
0.21 \\
0.30 \\
0.49 \\
0.58\end{array}$ & $\begin{array}{l}0.0028 \\
0.0043 \\
0.0059 \\
0.0095 \\
0.0116\end{array}$ \\
\hline " & $\begin{array}{l}0.65 \\
0.75 \\
0.96 \\
1.00\end{array}$ & $\begin{array}{l}0.0176 \\
0.0203 \\
0.0260 \\
0.0275\end{array}$ & $\begin{array}{l}0.77 \\
0.96 \\
1.00\end{array}$ & $\begin{array}{l}0.0188 \\
0.0235 \\
0.0241\end{array}$ & $\begin{array}{l}0.65 \\
0.75 \\
0.96 \\
1.00\end{array}$ & $\begin{array}{l}0.0145 \\
0.0163 \\
0.0211 \\
0.0216\end{array}$ & $\begin{array}{l}0.68 \\
0.77 \\
0.96 \\
1.00\end{array}$ & $\begin{array}{l}0.0133 \\
0.0155 \\
0.0190 \\
0.0200\end{array}$ \\
\hline $\begin{array}{l}50 \\
" \prime \\
" \prime\end{array}$ & $\begin{array}{l}0.20 \\
0.35 \\
0.49 \\
0.65\end{array}$ & $\begin{array}{l}0.0035 \\
0.0060 \\
0.0085 \\
0.0110\end{array}$ & $\begin{array}{l}0.21 \\
0.35 \\
0.46 \\
0.62\end{array}$ & $\begin{array}{l}0.0031 \\
0.0053 \\
0.0070 \\
0.0095\end{array}$ & $\begin{array}{l}0.18 \\
0.33 \\
0.51 \\
0.59\end{array}$ & $\begin{array}{l}0.0025 \\
0.0045 \\
0.0070 \\
0.0082\end{array}$ & $\begin{array}{l}0.21 \\
0.36 \\
0.49 \\
0.65\end{array}$ & $\begin{array}{l}0.0025 \\
0.0043 \\
0.0060 \\
0.0080\end{array}$ \\
\hline " & $\begin{array}{l}0.80 \\
0.92 \\
1.00\end{array}$ & $\begin{array}{l}0.0135 \\
0.0155 \\
0.0170\end{array}$ & $\begin{array}{l}0.78 \\
0.92 \\
1.00\end{array}$ & $\begin{array}{l}0.0118 \\
0.0140 \\
0.0150\end{array}$ & $\begin{array}{l}0.80 \\
0.93 \\
1.00\end{array}$ & $\begin{array}{l}0.0110 \\
0.0127 \\
0.0135\end{array}$ & $\begin{array}{l}0.80 \\
0.93 \\
1.00\end{array}$ & $\begin{array}{l}0.0098 \\
0.0115 \\
0.0127\end{array}$ \\
\hline $\begin{array}{l}60 \\
" \prime \\
" \prime\end{array}$ & $\begin{array}{l}0.21 \\
0.36 \\
0.51 \\
0.64\end{array}$ & $\begin{array}{l}0.0030 \\
0.0050 \\
0.0070 \\
0.0090\end{array}$ & $\begin{array}{l}0.23 \\
0.33 \\
0.51 \\
0.66\end{array}$ & $\begin{array}{l}0.0030 \\
0.0043 \\
0.0065 \\
0.0083\end{array}$ & $\begin{array}{l}0.22 \\
0.38 \\
0.50 \\
0.64\end{array}$ & $\begin{array}{l}0.0025 \\
0.0045 \\
0.0058 \\
0.0073\end{array}$ & $\begin{array}{l}0.25 \\
0.34 \\
0.49 \\
0.66\end{array}$ & $\begin{array}{l}0.0025 \\
0.0035 \\
0.0050 \\
0.0068\end{array}$ \\
\hline " & $\begin{array}{l}0.74 \\
0.84 \\
1.00\end{array}$ & $\begin{array}{l}0.0100 \\
0.0113 \\
0.0135\end{array}$ & $\begin{array}{l}0.84 \\
1.00\end{array}$ & $\begin{array}{l}0.0108 \\
0.0125\end{array}$ & $\begin{array}{l}0.75 \\
0.84 \\
1.00\end{array}$ & $\begin{array}{l}0.0085 \\
0.0098 \\
0.0115\end{array}$ & $\begin{array}{l}0.85 \\
1.00\end{array}$ & $\begin{array}{l}0.0090 \\
0.0105\end{array}$ \\
\hline $\begin{array}{l}70 \\
" \prime \\
" \prime \\
" \prime\end{array}$ & $\begin{array}{l}0.24 \\
0.40 \\
0.59 \\
0.72 \\
0.89 \\
1.00\end{array}$ & $\begin{array}{l}0.0030 \\
0.0048 \\
0.0068 \\
0.0085 \\
0.0103 \\
0.0115\end{array}$ & $\begin{array}{l}0.26 \\
0.45 \\
0.57 \\
0.75 \\
0.90 \\
1.00\end{array}$ & $\begin{array}{l}0.0028 \\
0.0048 \\
0.0060 \\
0.0078 \\
0.0095 \\
0.0105\end{array}$ & $\begin{array}{l}0.38 \\
0.60 \\
0.76 \\
0.92 \\
1.00\end{array}$ & $\begin{array}{l}0.0035 \\
0.0058 \\
0.0075 \\
0.0090 \\
0.0095\end{array}$ & $\begin{array}{l}0.25 \\
0.33 \\
0.58 \\
0.77 \\
0.93 \\
1.00\end{array}$ & $\begin{array}{l}0.0020 \\
0.0028 \\
0.0053 \\
0.0070 \\
0.0084 \\
0.0090\end{array}$ \\
\hline
\end{tabular}

Table 3 Experimental value $d_{1}$, $d_{2}$ of Eq. (11)

\begin{tabular}{lccccc}
\multicolumn{5}{c}{ Temperature of $\mathrm{NaCl}$ soln $\left[{ }^{\circ} \mathrm{C}\right]$} \\
\\
& 30 & $\ldots 0$ & 50 & 60 & 70 \\
\hline$d_{1}$ & $4.55 \times 10^{-3}$ & $3.40 \times 10^{-2}$ & $2.75 \times 10^{-2}$ & $2.25 \times 10^{-2}$ & $1.80 \times 10^{-2}$ \\
$d_{2}$ & $0.850 \times 10^{-4}$ & $0.603 \times 10^{-4}$ & $0.495 \times 10^{-4}$ & $0.400 \times 10^{-4}$ & $0.300 \times 10^{-4}$
\end{tabular}

$$
p\{\mathrm{HClO}\}=-\mathrm{pH}+a_{0}
$$

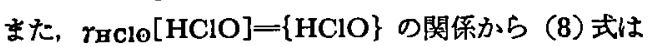
(9) 式で示される。

$$
p[\mathrm{HClO}]=-\mathrm{pH}+a_{0}+\log \gamma_{\mathrm{HClO}}
$$

pHに対して活量係数 THClo を一定とし， $a_{0}+\log$ $\gamma_{\mathrm{HClO}}=a$ とすると（9）式は（5）式と同一の式になる.

. [HClO] が無視できる $\mathrm{pH} 2$ 以下の条件では, 前述の よ. $\mathrm{K}\left[\mathrm{Cl}_{2}\right.$ (active)] 考えることができるから，この $\mathrm{pH}$ 範囲で，直接に $\left[\mathrm{Cl}_{2}(\mathrm{aq})\right]+\left[\mathrm{Cl}_{3}-\right]$ を実測することができる。Table 2 および, Fig. 3〜6 は $\mathrm{pH} 1$ で温度 $30^{\circ} \mathrm{C}, 50^{\circ} \mathrm{C}, 60^{\circ} \mathrm{C}$, $70^{\circ} \mathrm{C}$, 食塩濃度 $217 \mathrm{~g} / \mathrm{L}, 250 \mathrm{~g} / \mathrm{L}, 280 \mathrm{~g} / \mathrm{L}, 300 \mathrm{~g} / \mathrm{L}$, の食塩水について, 塩素分圧と溶解度の関係を求めたる のである。同図に示されるよ5に [HClO] の無視でき る条件では直線関係が成立し（10）式に示すヘンリー の法則が成立することがわかる。
$\left[\mathrm{Cl}_{2}(\mathrm{aq})\right]+\left[\mathrm{Cl}_{3}{ }^{-}\right]=P \cdot k$

つきに食塩濃度に対する塩素溶解度の関保 を求めるため, 塩素分压を 1 atm とし, 食塩水 の $\mathrm{pH}$ を 1 と, 食塩水の食塩濃度を 217 $\mathrm{g} / \mathrm{L}$ から $300 \mathrm{~g} / \mathrm{L}$ まで变化させて, 塩素溶解 度を测定してその結果を Fig.7に示した。 同図に示されるように, $\left[\mathrm{Cl}_{2}(\mathrm{aq})\right]+\left[\mathrm{Cl}_{3}-\right]$ は食塩濃度 $N$ に対して直線関係であらかさ れ（10）から (11) 式の関俰が得られる。

$$
\left[\mathrm{Cl}_{2}(\mathrm{aq})\right]+\left[\mathrm{Cl}_{3}-\right]=P \cdot k=P\left(d_{1}-d_{2} N\right)
$$

各温度に打ける Fig. 7 に示された直線か 5，(11）式の $d_{1}, d_{2}$, を求めるとその值は Table 3 のよ 5になり, $\log d_{1}, \log d_{2}$, を絶 対温度の逆数，1/TK対して点緅すると Fig. 8 に示す関係が得られ，おのおのの直線から つきの関倸が求められる。

$$
\begin{aligned}
& d_{1}=2.21 \times 10^{-5} \times 10^{1000 / T} \\
& d_{2}=3.98 \times 10^{-8} \times 10^{1000 / T}
\end{aligned}
$$

(11) 式と (12)，(13）式がらヘンリー佰数 k は（14）式で,また $\left[\mathrm{Cl}_{2}(\mathrm{aq})\right]+\left[\mathrm{Cl}_{3}{ }^{-}\right]$は (15) 式であらわされる。

$$
\begin{aligned}
& k=(2.2 \mathrm{I}-0.00398 \mathrm{~N}) \times 10^{-5} \times 10^{1000 / \mathrm{T}} \\
& {\left[\mathrm{Cl}_{2}(\mathrm{aq})\right]+\left[\mathrm{Cl}_{3}^{-}\right]=P(2.21} \\
& \quad-0.00398 \mathrm{~N}) \times 10^{-5} \times 10^{1000 / \mathrm{T}}
\end{aligned}
$$

$k$ vs. $T$ の実験式の意味を解するために（14）式の自 然対数をとり整理すると（16）式のよ5になる。

$$
l_{n} k=l_{n}\left[\left(2.21-0.00398 N \times 10^{-2}\right]+2303\left(\frac{1}{T}-\frac{1}{333}\right)\right.
$$

(16) 式において $T_{1}=333^{\circ} \mathrm{K}$ に対する $k$ の值 $k_{1}$ は, Table 3 によると $(2.21-0.00398 N) \times 10^{-2}$ に近い値 を示すから， $k_{1}=(2.21-0.00398 \mathrm{~N}) \times 10^{-2}$ とすると。 (16）式は（17）式であらわされる。

$$
l_{n} \frac{k}{k_{1}}=2303\left(\frac{1}{T}-\frac{1}{T_{1}}\right)
$$

一方ガスが液に溶解する平衡に対して, Van't Hofr の恒圧平衡式が適用でき，(18）式に示すよ5に佰王の もとに平衡恒数 $K$ の温度变化は気相における 配分モル エンタルピーと液相に括ける配分モルェンタルピーの差 $\Delta H$ であらわされる。

$$
\left(\frac{\partial l_{n} K}{\partial T}\right)_{p}=\frac{\Delta H}{R T^{2}}
$$

ここで本溶解平衡を $\mathrm{Cl}_{2}$ (気相) $\rightleftharpoons \mathrm{Cl}_{2}$ (液相) の不均 一相の平衡と考え，気相と液相の溶質成分の活量をそれ ぞれ $a_{y}, a_{!}$とすると，平衡桓数 $K$ は (19) 式であらわ 


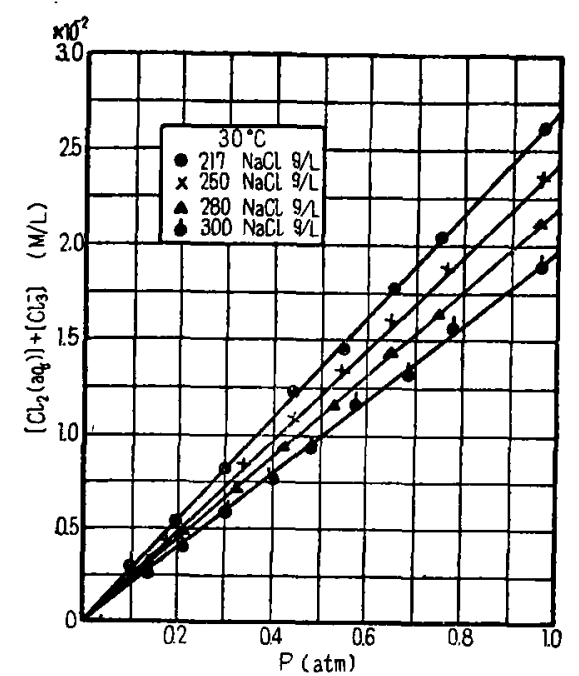

Fig. 3 Correlation between $P$ and concentrations of unhydrolyzed chlorine at $30^{\circ} \mathrm{C}$

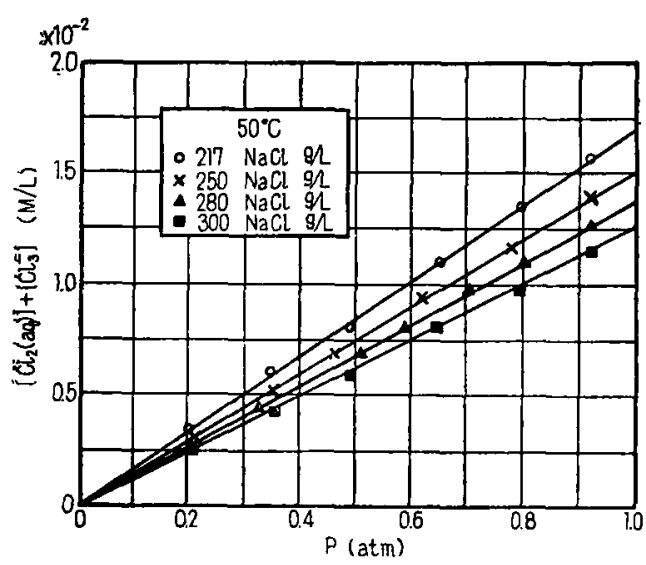

Fig. 4 Correlation' between $\mathrm{P}$ dnd concentrations of unhydrolyzed chlorine at $50^{\circ} \mathrm{C}$

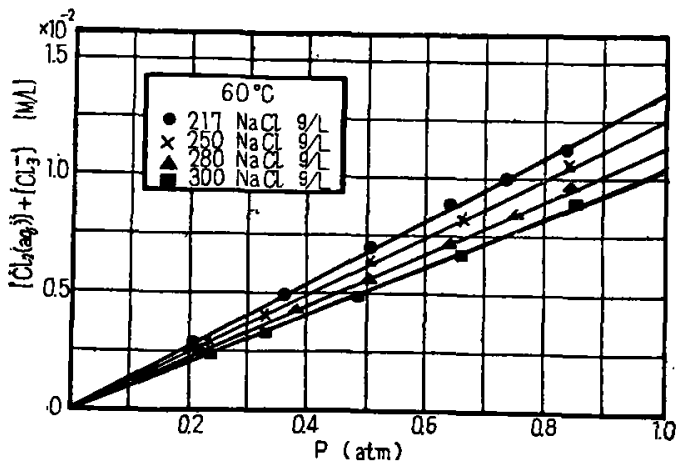

Fig. 5 Correlation between $P$ and concentrations of unhydrolyzed chlorine at $60^{\circ} \mathrm{C}$

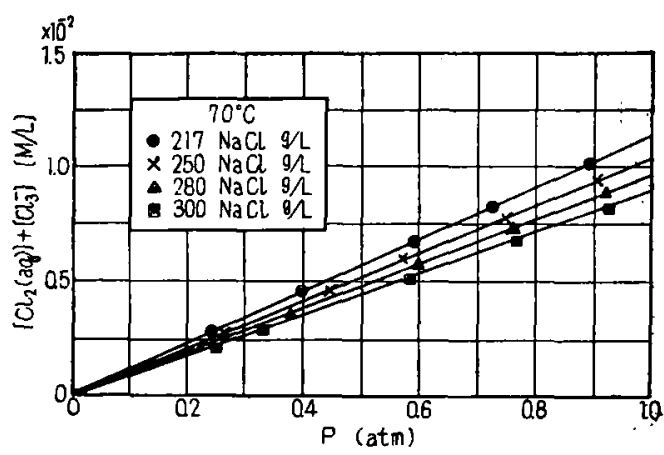

Fig. 6 Correlation between $P$ and concentrations of unhydrolydrolyzed chlorine at $70^{\circ} \mathrm{C}$

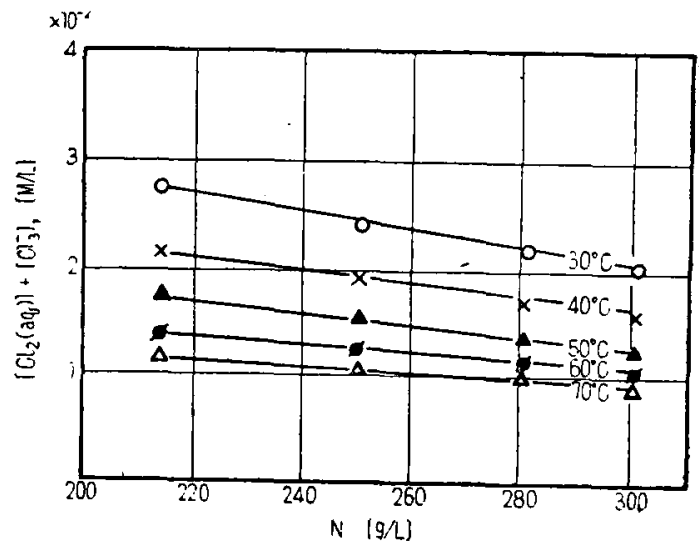

Fig. 7 Correlation between concentrations of unhydrolyzed chlorine and concentrations of $\mathrm{Nacl}$ soln

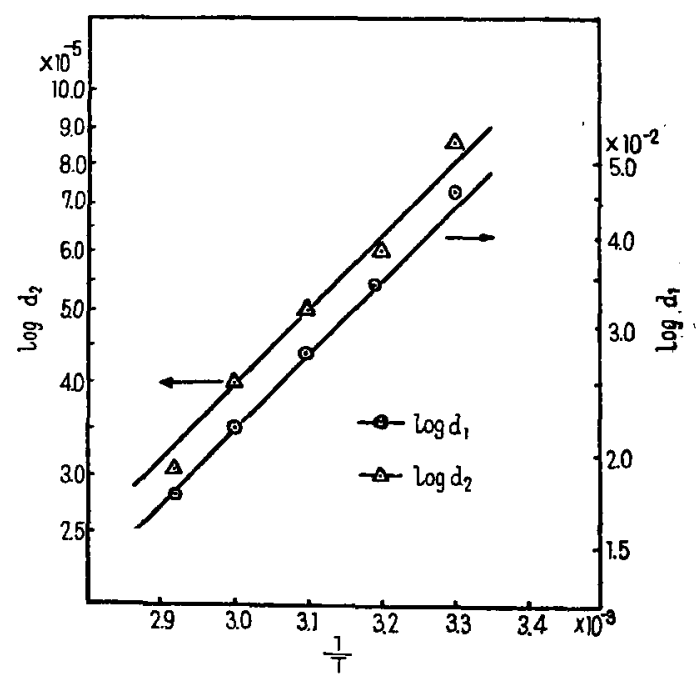

Fig. 8 Correlation between $d_{1}, d_{2}$ in Eq. (11) and temperature 
される。

$$
l_{n} K=l_{n} a_{l}-l_{n} a_{g}
$$

理想気体技よび理想溶液を仮定すると， $a_{0}$ 和よび $a_{1}$ はそれぞ机力 $P$ およびモル分率 $x$ であらわすことが できるから，(19）式は（20）式となる。

$$
l_{n} K=l_{n} x-l_{n} P
$$

ヘンリーの法則 $x=k^{\prime} P$ の関係から (20) 式は $l_{n} K=$ $l_{\mathrm{n}} k^{\prime}$ となり，(18）式から（21）式が得られる。

$$
\left(\frac{\partial l_{n} k^{\prime}}{\partial T}\right)_{p}=\frac{\Delta H}{R T^{2}}
$$

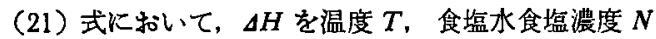
に対して二定とすると，(21）式の積分形は（22）式で あらわされる。

$$
l_{n} \frac{k^{\prime}}{k_{1}^{\prime}}=-\frac{\Delta H}{R}\left(\frac{1}{T}-\frac{1}{T_{1}}\right)
$$

ここにモル分率基準の恒数 $k^{\prime}, k_{1}{ }^{\prime}$ はそれぞれ $T, T_{1}$

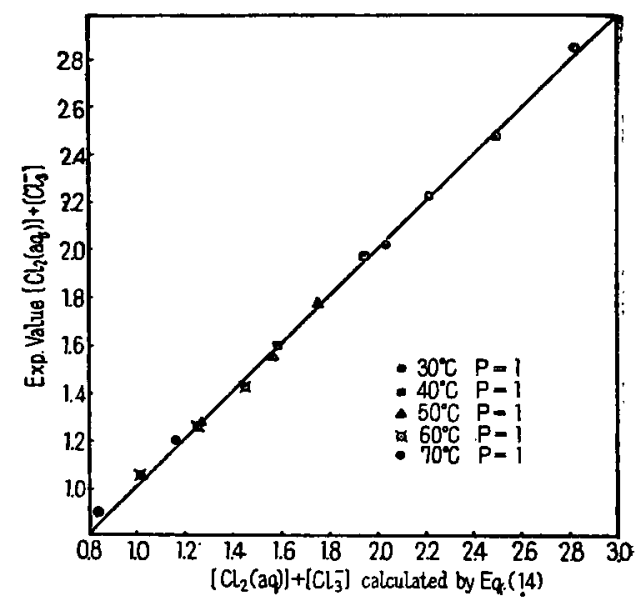

Fig. 9 Comparison of Experimental Data with values of $\left[\mathrm{Cl}_{2}(\mathrm{aq})\right]+\left[\mathrm{Cl}_{\mathrm{a}}^{-}\right]$calculated by Eq. (14)

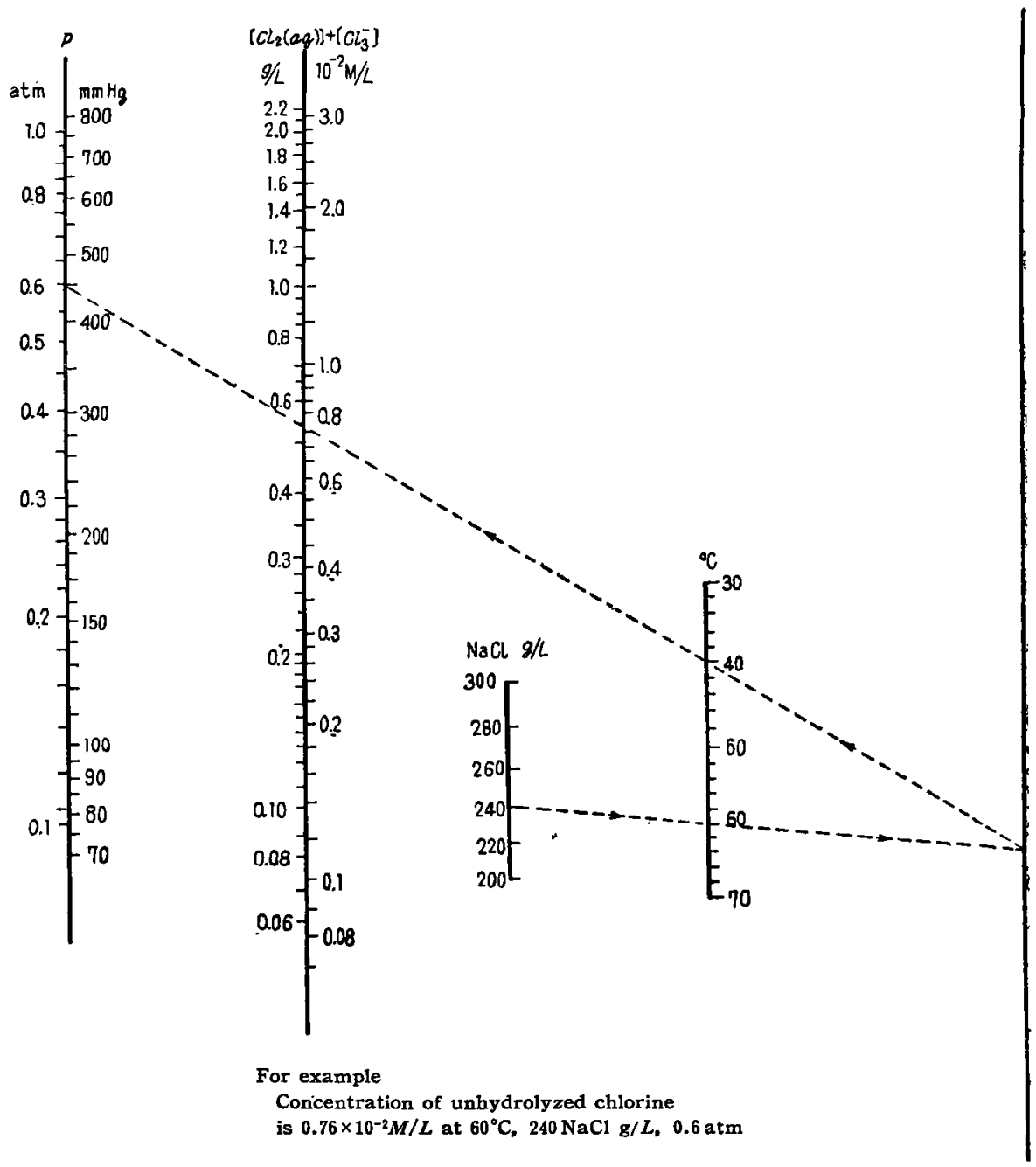

Fig. 10 Nomograph for solubilities of unhydrolyzed chlorine in concentrated sodium chloride solution 
飞対応するか，濃度 $(M / L)$ 基準の恒数 $k, k_{1}$ 同しく $T, T_{1}$ 飞対応せ七あ，溶液の恒容である条件を入れると $k / k_{1}=k^{\prime} / k_{1}{ }^{\prime}$ の関係が成立するから，(22）式は（23） 式となる。

$$
l_{n} \frac{k}{k_{1}}=-\frac{\Delta H}{R}\left(\frac{1}{T}-\frac{1}{T_{1}}\right)
$$

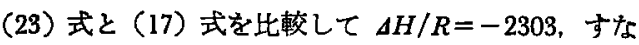
わち $R=1.987, \Delta H=-4575$ とすると両式は一致する から, エンタルピーの変化 $\Delta H$ (溶解熱相当する) が $-4575 \mathrm{cal} / \mathrm{M}$ を示すことになる。

以上のように（14）式は $\mathrm{Van}^{\prime} t$ Hoff の恒圧平衡式 の平衡恒数を（10）战よび（11）式で示されるへンリー 佰数 $k$ とし温度和よび食塩水食塩濃度の本実験範囲で $\Delta H$ を一定として積分した形（23）式代扣いて， $T_{1}=$ $333^{\circ} \mathrm{K}$ に対応する $k_{1}$ を基準值とした $k$ vs $T$ の関倸を 示するのである。な（14）式によって，塩素分压 $P 0.1$ $\sim 1 \mathrm{~atm}$, 温度 $30 \sim 70^{\circ} \mathrm{C},\left(T=303 \sim 343^{\circ} \mathrm{K}\right)$, 食程水食 塩濃度 $N 200 \sim 300 \mathrm{~g} / \mathrm{L}$ の筃囲で $k$ を算出し，その值と 実測值の比較を Fig. 9 で示し（14）式が実測值とよく 一致することを明らがした。

Fig. 10 は（15）式の算出を容易にするために，その 関保をノモグラフに作図したるのである。塩素の溶解度 は，緟密には，前述のように Tabie I K示された $a$ の値 に上って，(6) 式から [HClO] を算出し，先の值を(15) 式あるい怯 Fig. 10 汇よって求められる $\left[\mathrm{Cl}_{2}(\mathrm{aq})\right]+$ $\left[\mathrm{Cl}_{3}{ }^{-}\right]$の值に加算する必要があるが、アルカリが，添加 されて $\mathrm{pH}$ が高くなっている特別の場合を除いては，濃 厚食塩水についての本実験 式の適用範囲では [HClO] はきわめて小さく $\left(10^{-3.9} \mathrm{M} / \mathrm{L}\right.$ 以下), [HClO] は無視 することができる。

\section{5. 結 言}

港厚食塩水の塩素の溶解度は, $\left[\mathrm{Cl}_{2}(\mathrm{aq})\right],\left[\mathrm{Cl}_{3}-\right]$, [HClO] の総和として示され， $\mathrm{pH} 2$ 以下では近似的に [HClO] は無視でき，塩素分圧と溶解度の関係はヘンリ 一の法則が成立する。

$\mathrm{pH} \mathrm{l}$, 塩素分圧 $1 \mathrm{~atm}$, 温度 $30,50,60,70^{\circ} \mathrm{C}$, 食塩 水食塩濃度 $217 \mathrm{~g} / \mathrm{L}$ から $300 \mathrm{~g} / \mathrm{L}$ の条件で，塩素の溶解 度の実測值を示し, $\left[\mathrm{Cl}_{2}(\mathrm{aq})\right]+\left[\mathrm{Cl}_{3}-\right.$ ] であらわした。

$$
\begin{aligned}
& {\left[\mathrm{Cl}_{2}(\mathrm{aq})\right]+\left[\mathrm{Cl}_{3}{ }^{-}\right]} \\
& \quad=P(2.21-0.00398 \mathrm{~N}) \times 10^{-5} \times 10^{1000 / \mathrm{T}}
\end{aligned}
$$

またこの実験式から，Fig.10に示したノモグラフを 作図した。

付記：本研究に怙いて，いろいろ御指羊いただいた
京大工学部岡田辰三教授, 吉沢四郎教授, 高松武一郎助

教授に厚く感謝致します。

\section{Nomenclature}

$a_{1}$ : Constant in Eq. (5)

$a_{g}$ : Activity of solute component in gas phase

$[\mathrm{M} / \mathrm{M}]$

$a_{l}$ : Activity of solute component in liquid phase

$[\mathrm{M} / \mathrm{M}]$

$a_{0}:$ Constant in Eq. (8)

$C:$ Concentration of chlorine in liquid $[\mathrm{g} / \mathrm{L}]$

$d_{1}$ : Constant in Eq. (I1)

$d_{2}$ : Constant in Eq. (11)

$\Delta H$ : Change in enthalpy

$K$ : Equilibrium constant in Eq. (18), (19)

$K_{1}:=(70.9)^{2} k_{0}, k_{0}:$ Hydrolysis constant on molal basis

$K_{2}$ : Equilibrium constant in Eq. (6)

$k:$ Henry's constant in Eq. (10) [M/L·atm]

$k_{1}: k$ at $T_{1}$ $[\mathrm{M} / \mathrm{L} \cdot \mathrm{atm}]$

$k^{\prime}$ : Henry's constant on basis of mol fraction

$[\mathrm{M} / \mathrm{M} \cdot \mathrm{atm}]$

$k_{1}^{\prime}: k^{\prime}$ at $T_{1}$ $[\mathrm{M} / \mathrm{M} \cdot \mathrm{atm}]$

$N$ : Concentration of $\mathrm{NaCl}$ soln $\quad[\mathrm{g} / \mathrm{L}]$

$P$ : Partial Pressure of chlorine gas [atm]

$R:$ Gas constant $\quad\left[\mathrm{L} \cdot \mathrm{atm} / \mathrm{M}^{\circ} \mathrm{K}\right]$

$T$ : Absolute temperature

$T_{1}$ : Absolute temperature of a given state

$\bar{v}:$ Molal volume $[\mathrm{L} / \mathrm{M}]$

$x$ : Mol fraction of solute component in liquid phase

[M/M]

$r$ : Ratio of concentration of unhydrolyzed chlorine in water to concentration of chlorine in gas phase

raclo: Activity coefficient of $\mathrm{HClO}$

$\mu:=P \bar{v} / R T$

\{\}$:$ Activity in liquid

$[\mathrm{M} / \mathrm{L}]$

[ ] : Concentration in liquid

$[\mathrm{M} / \mathrm{L}]$

\section{Literature cited}

1) Adams and Edmonds: Ind. Eng. Chem. 29, 449 (1937)

2) Jakowkin: Z. Phys. Chem. 29, 613 (1899)

3) Ogizawa. H. : Riken-Soho, 20, 999 (1941)

4) Ogizawa, H. : Riken-Soho, 19, 1220 (1940)

5) F. Foerster and E. Müller : Z. Elektrochem, 51, 921(1902)

6) P. Whitney and J, E. Vivian : Ind. Eng. Chem., 33, 742 (1941)

7) E. F. Izard : J. Am. Chem. Soc., 53, 1667 (1951)

8) Lars Barr: J. Electro. Chem. Soc., 101, 497 (1954) 


\title{
Solubilities of Chlorine in Concentrated Sodium
}

\section{Chloride Solution}

\author{
Noriyuki Yokota*
}

A study was made of the effect of $P, N, T$ and $\mathrm{pH}$ on the solubilities of chlorine in concentrated sodium chloride solution.

The experimental range of $P$ was from 0.1 to $1.0 \mathrm{~atm}, N$ from 210 to $300 \mathrm{~g} / \mathrm{L}, T$ from 303 to $343^{\circ} \mathrm{K}$ (from 30 to $70^{\circ} \mathrm{C}$ ), $\mathrm{pH}$ from 1 to 5 . The results obtained of the solubilities which might be cosidered the sum of $\left[\mathrm{Cl}_{2}(\mathrm{aq})\right],\left[\mathrm{Cl}_{3}{ }^{-}\right]$and $[\mathrm{HClO}]$ were as follows :

The effect of $\mathrm{pH}$ on [HClO] is given by Eq. (5). In the range of $\mathrm{pH}$ less than 3 , where [HClO] is found to be approximately negligible, the relation between solubilities and $P$ is explained by Henry's law, [Eq. (10),] and the effect of $N$ by Eq. (11). Hence, calculation of the solubilities of unhydrolyzed chlorine in th $\mathrm{pH}$ range given above are made by means of the following empirical equation :

$$
\left[\mathrm{Cl}_{2}(\mathrm{aq})\right]+\left[\mathrm{Cl}_{3}-\right]=P(2.21-0.00398 \mathrm{~N}) \times 10^{-5} \times 10^{\frac{1000}{\mathrm{~T}}}
$$

where $P=0 \sim 1.0, N=200 \sim 300$, and $T=303 \sim 343$.

This value can also be obtained graphically by employing the nomograph of Fig. 10 which is prepared from the above equation.

* Osaka Soda Co.

\section{化学工学技術専門視察団 アメリカ通信}

第1昜 6 月6日 $\mathrm{AM} 12.30 \quad 5$ 日夜 10 時盛大な 持見送りを跡に羽田を出発同日午後4 時頃ホノルルに到 㯰しました。当地は風物，人物とも原色にあふれ，さす が南の常夏の国にきた感じを梁くしました。諸手続きす 無事に終り，一部の方々は早々寸眼をおしんでワイキキ の浜などにドライプされたりちょっとした買物をしたり しましたがどうやら用を足せるので一同意を強くした 论第です。

約 4 時間後同地を出発 6 日朝 6 時頃サンフランシスコ 记着きした。空港には Project manager や通訳の方 々が出迎えておられ親切に世話をして頂いています。

同自動車にて Sheraton Hotel一相当立派一に落付き ました。

少し休んだ後早速通訳の方の引卒のもと, キフフェテ “隹けドラッグストフーなどを見学かたがた用足しK行 きました。アメリカ人はなかなかわれわれに親切なよ5 です「万事経験」と云う処です。

午後1時より最初の Orientation meeting があり， 橗自拈よび明後日は休みの予定です。
一同元気で愉快にやっていますから御休心下さい。 なおいまのところたいした赤毛布は残念ながらありま せんので御知らせできません。ではまた。 （日，時間は全部現地の時間です）

第2号 6 月10日夜 6 日サンフランシスコ到着 後， 7 (土)，8（日）と 2 日間市内見物をしたり英気を 養っていましたが，9日（月）には，第1回の訪間先で ある Shell Oil Developement Co. (Emeryville にあ り自動車にて䄪 40～50分の所）に参りましたここは 全 Shell Co. の研究部門であり，各種の中間試験装居や

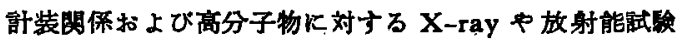
蚊置などを充分火見，かつディスカッションをさして项 き，大いにうるところがありました。

本 10 日は朝 5 時 30 分頃起床しホテルを出発，飛行機 にて白雪を頂くシェラネバダの山ネを下に見, 統いて壮 大なグランドキャニオンを鿓でつつダレス経由, 当七= ーストンに午後 4 特 30 分頃無事到着しました。

(以下 491 ページ余白へつつく） 